\title{
Recombinant human growth hormone enhances tibial growth in peripubertal female rats but not in males
}

\author{
M A Rol De Lama, A Pérez-Romero, J A F Tresguerres, M Hermanussen ${ }^{1}$ and C Ariznavarreta \\ Department of Physiology, Faculty of Medicine, Complutense University, 28040 Madrid, Spain and ${ }^{1}$ Aschauhof, Altenhof, Germany \\ (Correspondence should be addressed to J A F Tresguerres; Email: guerres@eucmax.sim.ucm.es)
}

\begin{abstract}
Objective: A novel non-invasive technique termed microknemometry, which allows daily leg length measurement, was used to investigate the growth promoting effect of growth hormone $(\mathrm{GH})$ on peripubertal rats. We compared the effect of different patterns of recombinant human (rh) GH administration to peripubertal male rats with the effect produced by two daily administrations of the same amount of rhGH to peripubertal female rats or adult male rats. Another group of peripubertal male rats was also submitted to a 3-day period of starvation, in order to study catchup growth during refeeding and to determine whether this process could be stimulated by exogenous $\mathrm{GH}$ administration.

Results: GH treatment was unable to stimulate tibial growth or weight gain in peripubertal males, whereas a clear growth promoting effect was observed in female rats and also in adult male rats. Starvation caused a dramatic body weight loss, and a reduction in tibial growth rate. Peripubertal male rats gained body weight faster than unstarved animals during refeeding, although recovery was not complete after nine days. Tibial growth, however, was resumed at the same speed as in normally fed males. This means that no catch-up effect was observed after refeeding in animals either with or without GH treatment.

Conclusions: During peripuberty, normal male rats grow at a maximal speed that cannot be further increased by exogenous GH treatment, whereas age-matched female rats or older males grow at a slower rate than peripubertal males. Thus, exogenous rhGH administration is capable of enhancing growth velocity.
\end{abstract}

European Journal of Endocrinology 142 517-523

\section{Introduction}

A novel non-invasive leg length measuring technique, microknemometry (1-5), offers new possibilities when studying body growth in experimental animals. This technique allows daily measurement of tibial growth in vivo, and represents a significant improvement over other kinds of estimations of this process, such as those obtained from oxytetracycline deposition or radiographical methods which may cause damage to growth processes. Other growth evaluation methods, such as body weight, nose-tail length, or tail length cannot substitute for long bone growth estimations since long bones are the only ones that respond to growth hormone $(\mathrm{GH})$ in a dose-dependent manner (6).

The growth promoting effect of recombinant human (rh) GH on dwarf rats (7) or hypophysectomized rats (8) is well known. GH has also been reported to be effective in promoting growth in normal animals during the active growing period. However, and although not specifically stated, those studies have been conducted on female rats $(9,10)$. We wanted to determine, using microknemometry, if the growth rate in peripubertal male rats could also be enhanced by exogenous rhGH, comparing the results with those obtained by treating age-matched females and/or adult male rats.

Catch-up growth is a common phenomenon following periods of growth arrest produced by starvation, illness or other reasons. It consists of an increased growth rate that tries to compensate for growth loss during growth arrest, in order to re-establish normal size. This process has previously been investigated in rats, studying changes in weight $(11,12)$, or body and tail length variations (13) as growth indices. The present study was carried out using microknemometry in order to investigate the dynamics of long bone growth after food restriction and the possible existence of supraphysiological growth rates during refeeding (catch-up growth).

\section{Materials and methods}

These studies were conducted in accordance with the principles and procedures outlined in the NIH Guide for the Care and Use of Laboratory Animals. 


\section{Animals and accommodation}

Female and male Wistar rats were kept under controlled conditions of light (12 h light/ $12 \mathrm{~h}$ darkness), and temperature $\left(21 \pm 2{ }^{\circ} \mathrm{C}\right)$, and were fed with tap water and rat chow (Panlab, Barcelona, Spain) available ad libitum (except those starved in experiment 4). Animals were weighed daily and their tibial length was also measured daily by microknemometry. rhGH was used for treatments (Saizen, Serono, Madrid, Spain). Animals were killed by decapitation at the end of the observation period at $0900 \mathrm{~h}$, trunk blood was then collected and centrifuged to extract the plasma which was kept at $-20{ }^{\circ} \mathrm{C}$ for hormone determinations by specific radioimmunoassays.

\section{Growth measurement}

Bone growth was measured by microknemometry $(1-5)$, which is performed on conscious animals. The mean technical error of the microknemometer is about $60 \mu \mathrm{m}$, implying that growth can be monitored daily as this error represents approximately $10 \%$ of the rat's daily average growth, which amounts to about $550 \mu \mathrm{m} /$ day for a 40-day-old male rat. The microknemometer is a digital goniometer, connected to two measuring arms with metallic holders which grasp the rear leg between the knee and the heel. Each measurement consists of 4 independent estimations of the leg length. The animal could move freely between each measurement.

\section{Growth hormone and insulin-like growth factor (IGF)-I measurements}

Plasma GH levels were determined by double antibody RIA as previously described $(14,15)$, using anti-rGH-S-5 specific rat (r) antibody and rat GH RP2 as the standard. All the materials were kindly provided by the NIDDK (Bethesda, MD, USA). The iodination of the rat GH I-6 was performed using the lactoperoxidase method. The sensitivity of the curve was $25 \mathrm{pg} / \mathrm{ml}$. The intra-assay and interassay coef-ficients of variation were $5.7 \%$ and $9.4 \%$. The IGF-I used for iodination (by the chloramine $\mathrm{T}$ method) and for the standard curve dilution was $\mathrm{A}$ 52-EDP-186 (Lilly Company, Indianapolis, IN, USA). The antibody (UB2-495) was provided by the NIDDK. The assay was performed as previously described (1517): IGF-I binding proteins were separated by acid ethanol extraction (16). The sensitivity of the curve was $10 \mathrm{pg} / \mathrm{ml}$, and the intra-assay and interassay coefficients of variation were $7.8 \%$ and $12.9 \%$. IGF-I RIA was validated (18) by analyzing the correlation between the IGF-I reference curve and dilution curves of extracted samples, showing a high degree of parallelism. Mean recovery of labeled IGF-I preincubated with several samples before acid ethanol extraction was $83 \%$. Separation of extracted plasma with dextran charcoal showed that it was $98 \%$ free of binding proteins whereas the unextracted plasma showed only $43 \%$ free IGF-I.

\section{Experimental designs}

First experiment Twenty peripubertal male rats were submitted to either once daily s.c. injection of $1 \mathrm{IU}$ rhGH $(n=10)$, or the corresponding volume of saline $(n=10)$, from days 28 to 58 of life, thus covering the entire pubertal growth period.

Second experiment Forty-one peripubertal male rats were divided into 6 groups: three groups of animals received once daily s.c. injection of $1 \mathrm{IU}$ rhGH at $1000 \mathrm{~h}$ (Group A, $n=7$ ), $1400 \mathrm{~h}$ (Group B, $n=7$ ), or $1900 \mathrm{~h}$ (Group C, $n=7$ ). Another group received the same dose but it was divided into 3 injections at $1000 \mathrm{~h}, 1400 \mathrm{~h}$ and $1900 \mathrm{~h}$ (Group D, $n=7$ ), and the next group also received the same GH dose although under a continuous administration regimen (Group E, $n=6$ ). An Alzet (Alza Corporation, Palo Alto, CA, USA) osmotic pump implanted subcutaneously under ether anesthesia performed the continuous administration. The control group received 3 daily s.c. saline injections (Group F, $n=7$ ). These treatments were maintained from days 38 to 51 of life.

Third experiment Nine peripubertal female rats were treated with $1 \mathrm{IU}$ rhGH divided into two daily s.c. injections at $1000 \mathrm{~h}$ and $1600 \mathrm{~h}$, whereas another 10 females were injected at the same times with the same volume of saline. The treatment was maintained from days 25 to 60 of life.

Fourth experiment Eight adult male rats $(379 \pm 8.6 \mathrm{~g})$ were treated with $1 \mathrm{IU}$ rhGH divided into two daily s.c. injections at $1000 \mathrm{~h}$ and $1600 \mathrm{~h}$ from days 96 to 123 of life. Another 10 age-matched males $(379 \pm 11.3 \mathrm{~g})$ were injected with saline and served as controls.

Fifth experiment Thirty-one peripubertal male rats were ad libitum fed from days 27 to 32 of life and thereafter underwent different feeding regimens. Groups A, B, C and D received no food on day 33 and only $30 \%$ of the usual daily amount during the following two days. After this period, food was again available ad libitum until day 44. Group E (control) had food available $a b$ libitum for the whole period of time. Group B received a single daily injection of $1 \mathrm{IU}$ rhGH between days 35 and 38. Likewise, Groups C and $\mathrm{D}$ received a single daily $\mathrm{rhGH}$ injection ( $1 \mathrm{IU} / \mathrm{rat} /$ day) between days 37 and 40, and 39 and 42 respectively.

\section{Statistical analysis}

Values are expressed as means \pm s.E.M. The possible effect of GH treatment on growth was evaluated using a two-factor 


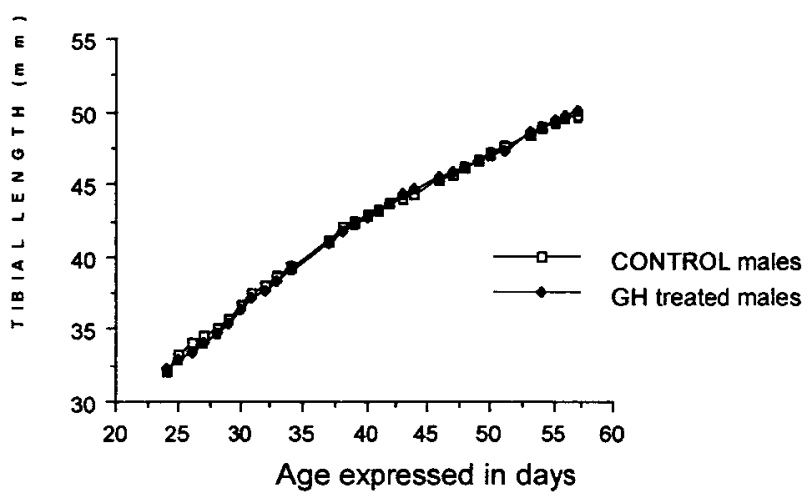

Figure 1 Mean tibial length ( \pm S.E.M.) corresponding to normal male rats from days 24 to 58 of life, either treated with once daily s.c. injection of $1 \mathrm{IU}$ rhGH from days 28 to 58 , or with saline. No differences were found between control or $\mathrm{GH}$-treated males.

analysis of variance (ANOVA) for repeated measures. To determine differences in temporal estimations such as final length, final weight or hormonal levels, a one-way ANOVA followed by a Scheffé test was performed. A Student's $t$-test was used when only two groups were compared. To study growth speed after food restriction and growth rate in old male rats, a linear regression analysis was used. Statistics were performed on an Apple Inc. Program (Stat View). The significance level was determined to be $P<0.05$.

\section{Results}

\section{First experiment}

No changes were found in either male rat tibial length (Fig. 1) or daily body weight evolution in response to exogenous rhGH s.c. administration (1 IU/day).

\section{Second experiment}

The same daily dose of rhGH was used from days 38 to 51 with different patterns of administration (i.e. one single injection at different times of the day, 3 injections per day or continuous s.c. infusion). GH was again unable to increase normal growth rate of tibial length or body weight in peripubertal males (Table 1).

Treatment with rhGH did not modify plasma IGF-I levels. However, all rhGH-treated groups showed a

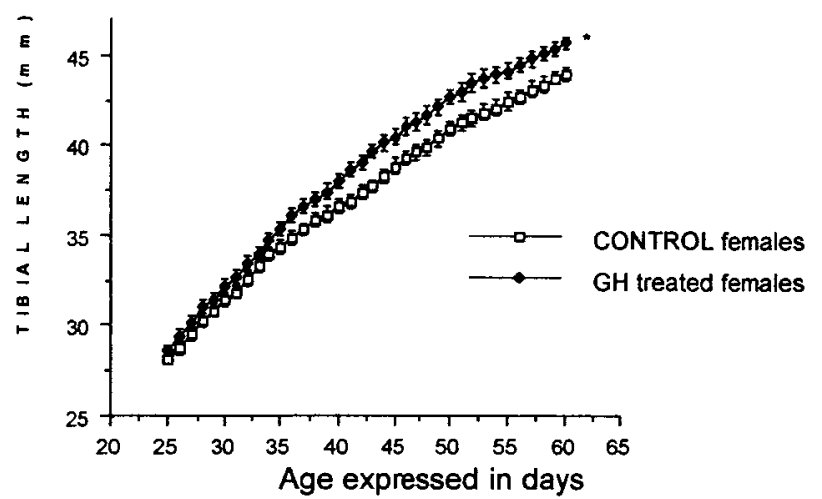

Figure 2 Mean tibial length ( \pm S.E.M.) corresponding to normal female rats from days 25 to 60 , treated with either $1 \mathrm{IU}$ rhGH administered in two daily s.c. injections of $0.5 \mathrm{IU}$ each or with saline during that period. GH administration significantly increased tibial growth rate, ${ }^{*} P<0.05$ vs control.

significant decrease in plasma $\mathrm{GH}$ levels $(P<0.01)$ when compared with the control group (Table 1).

\section{Third experiment}

$\mathrm{GH}$ administration to peripubertal female rats from days 25 to 60 significantly increased both tibial length growth rate (Fig. 2) and body weight (Fig. 3) as compared with control animals $(P<0.05$ vs control). As in the previous experiment, this treatment had no effect on plasma IGF-I levels (Fig. 4).

\section{Fourth experiment}

An evident reduction in growth rate with increasing age occurs in the rat $(2.76 \mathrm{~mm}$ of leg length growth in 30 days, compared with data in Table 1), almost reaching a plateau after 3 months. An increase in tibial length increment during the observation period was detected in GH-treated males, although insignificant when compared with controls (GH-treated males $3.01 \pm$ $0.3 \mathrm{~mm}$ vs controls $2.76 \pm 0.2 \mathrm{~mm}$ ). However, linear regression analysis showed a significantly higher slope in GH-treated males: control males 85.7 (confidence interval 95\% upper: 93.7, 95\% lower: 77.7); males $+\mathrm{GH}: 109.4$ (confidence interval 95\% lower: 100.4, 95\% upper 118.5). Plasma IGF-I levels were also significantly increased by the $\mathrm{GH}$ treatment (controls

Table 1 Mean tibial length and mean weight increments from days 38 to 50 in prepubertal male rats. Plasma GH levels on day 51 are also shown. Results are means \pm S.E.M.

\begin{tabular}{|c|c|c|c|c|c|c|}
\hline & Control & Group A & Group B & Group C & Group D & Group E \\
\hline $\begin{array}{l}\Delta \text { Body weight }(\mathrm{g}) \\
\Delta \text { Tibial length }(\mathrm{mm}) \\
\text { Plasma GH levels }(\mathrm{ng} / \mathrm{ml})\end{array}$ & $\begin{aligned} 111.7 & \pm 2.5 \\
5.77 & \pm 0.05 \\
59 & \pm 6.6^{*}\end{aligned}$ & $\begin{array}{c}112.6 \pm 3.2 \\
5.96 \pm 0.23 \\
8 \pm 1.4\end{array}$ & $\begin{array}{c}111.1 \pm 1.4 \\
6.16 \pm 0.24 \\
20 \pm 6.4\end{array}$ & $\begin{array}{c}118.3 \pm 5.4 \\
6.33 \pm 0.23 \\
25 \pm 8.7\end{array}$ & $\begin{array}{r}107.9 \pm 2.5 \\
5.95 \pm 0.3 \\
1.8 \pm 0.6\end{array}$ & $\begin{array}{r}103.3 \pm 4.3 \\
5.5 \pm 0.2 \\
9.7 \pm 3.4\end{array}$ \\
\hline
\end{tabular}

${ }^{*} P<0.01$ vs rest of the groups. 


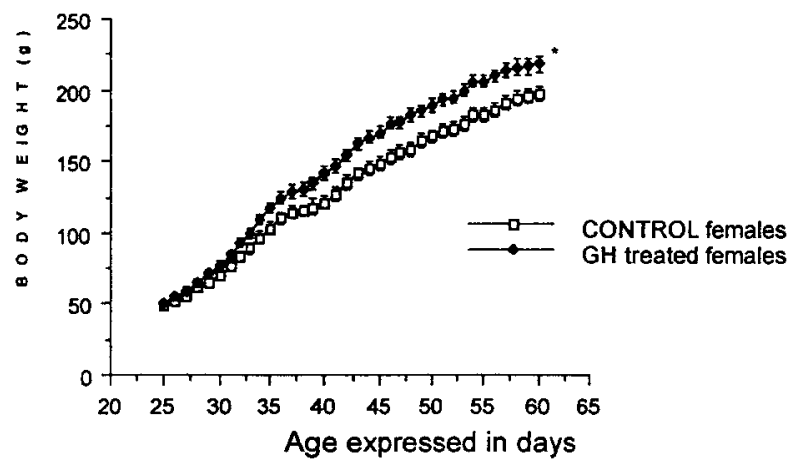

Figure 3 Mean body weight ( \pm S.E.M.) corresponding to normal female rats from days 25 to 60 , treated with either saline or with $1 \mathrm{IU}$ rhGH administered in two daily s.c. injections of $0.5 \mathrm{IU}$ each during that period. $\mathrm{GH}$ administration significantly increased body weight growth rate, ${ }^{\star} P<0.05$ vs control.

$1095.6 \pm 67.7 \mathrm{ng} / \mathrm{ml} \quad$ vs $\quad$ GH-treated $1344.4 \pm 66.53$ $\mathrm{ng} / \mathrm{ml})$.

\section{Fifth experiment}

Leg growth No statistical differences in tibial length or body weight could be seen among the different groups at the beginning of the experimental manipulation (day 31). Animals submitted to starvation exhibited a growth rate reduction during the period of food restriction when compared with ad libitum fed animals (starved $1.55 \pm 0.072 \mathrm{~mm}$ vs control $3.48 \pm 0.1$, $P<0.0005)$. During refeeding, leg length growth resumed at a pace that was indistinguishable from the control animals; consequently, all starved groups showed a smaller tibial average length than the control group on day $40 \quad(P<0.005$, Fig. 5). Figure 5 demonstrates that none of the rhGH treatments tested was able to stimulate catch-up growth. In order to investigate possible trends in tibial length recovery, the whole poststarvation period was submitted to a linear regression analysis. No significant differences in slopes

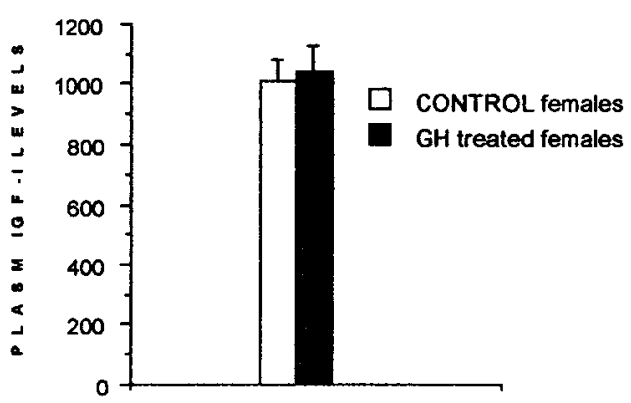

Figure 4 Mean ( \pm S.E.M.) plasma IGF-I levels corresponding to normal females, with or without $\mathrm{GH}$ treatment. GH treatment was maintained from days 25 to 60 and $1 \mathrm{IU}$ rhGH was administered in two daily s.c. injections of $0.5 \mathrm{IU}$ each. No effect on plasma IGF-I levels was observed.

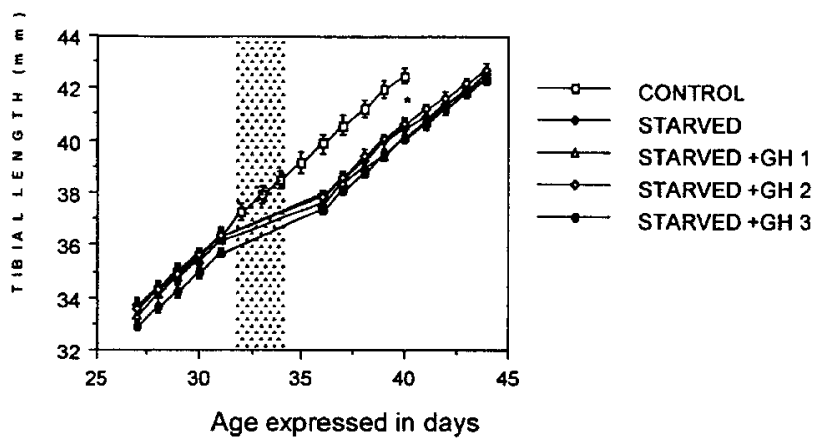

Figure 5 Mean tibial length ( \pm S.E.M.) corresponding to normal male rats from days 27 to 44 . The starvation period ( 3 days) is shown as a shaded band. GH treatments (1 IU rhGH/rat/day) were: from day 35 to day 38 of life $(\mathrm{GH} 1)$; from day 37 to day $40(\mathrm{GH} 2)$; from day 39 to day $42(\mathrm{GH} 3)$. ${ }^{*} P<0.005$ vs control. None of these treatments was able to stimulate catch-up growth.

were detected between starved and ad libitum fed animals, whether treated with GH or not (Table 2).

Body weight Starvation induced a dramatic weight loss. The weight variations during the 3-day period of food restriction were $-13.4 \pm 0.59 \mathrm{~g}$ for starved animals, and $38.3 \pm 1.48 \mathrm{~g}$ for ad libitum fed animals $(P<$ 0.001). Refeeding induced a significant weight gain during the first day in starved vs control animals (refed $21.6 \pm 0.76$, control $7.5 \pm 0.56, P<0.0001)$.

Weight gain during refeeding took place at a faster rate than in control animals as determined by simple regression analysis for the whole recovery period (Table 2).

Nevertheless, at the end of the observation period all the starved groups still displayed a significantly lower body weight when compared with controls (Fig. 6, $P<0.005)$. Exogenous rhGH administration during refeeding was not able to induce any stimulatory effects on body weight (Fig. 6).

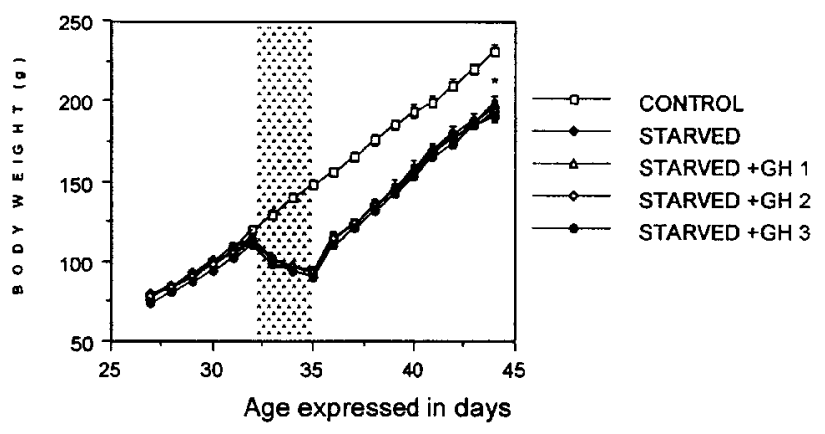

Figure 6 Mean body weight ( \pm S.E.M.) corresponding to normal male rats from days 27 to 44 . The starvation period ( 3 days) is shown as a shaded band. GH treatments ( $1 \mathrm{IU} \mathrm{rhGH/rat/day)} \mathrm{were:} \mathrm{from} \mathrm{day} 35$ to day $38(\mathrm{GH} 1)$; from day 37 to day $40(\mathrm{GH} 2)$; from day 39 to day 42 (GH 3). ${ }^{*} P<0.005$ vs control. No effect on body weight was induced by rhGH administration during refeeding. 
Table 2 Simple linear regression analysis of tibial leg length and body weight in relation to days of life, from days 36 to 40 in normal males.

\begin{tabular}{lccccc}
\hline & Ad libitum fed & Starved & Starved + GH 1 & Starved + GH2 & Starved + GH3 \\
\hline $\begin{array}{l}\text { Tibial length } \\
\text { Slope }\end{array}$ & 656.4 & 651.9 & 617.0 & 693.4 & 672.6 \\
$\begin{array}{l}\text { Confidence interval } \\
\quad 95 \% \text { lower }\end{array}$ & 592.3 & 596.6 & 521.4 & 607.7 & 614.4 \\
$\begin{array}{l}\text { 95\% upper } \\
\text { Body weight }\end{array}$ & 720.4 & 707.3 & 712.6 & 779.1 & 730.8 \\
$\begin{array}{l}\text { Slope } \\
\text { Confidence interval }\end{array}$ & 9.211 & 10.515 & 10.586 & 10.338 & 10.334 \\
$\quad \begin{array}{l}95 \% \text { lower } \\
\text { 95\% upper }\end{array}$ & 8.746 & 9.975 & 10.079 & 9.734 & 9.743 \\
\hline
\end{tabular}

Starved animals received no food on day 33 and only $30 \%$ of the usual daily amount during the following two days. GH treatments (1 IU $\mathrm{rhGH} / \mathrm{rat} /$ day) were $\mathrm{GH} 1$, from day 35 to 38 of life; GH2, from day 37 to $40 ; \mathrm{GH} 3$, from day 39 to 42 .

\section{Discussion}

In previous studies, exogenous GH subcutaneous administration, at doses lower than or similar to ours, in normal rats $(\sim 0.084 \mathrm{mg} / \mathrm{rat} / \mathrm{day}-0.4 \mathrm{mg} / \mathrm{rat} / \mathrm{day})$ (19-21), hypophysectomized rats $(0.128 \mathrm{mg} / \mathrm{rat} / \mathrm{day})$ (22), and dwarf rats ( $\sim 0.05 \mathrm{mg} / \mathrm{rat} /$ day) (23) has been shown to increase rat growth rate as measured by body weight or tail length. In our study, GH administration $(1 \mathrm{IU} /$ day $=0.3 \mathrm{mg} /$ day, in a single s.c. injection per rat) has proved to be ineffective in promoting tibial growth and body weight gain in peripubertal male rats. This lack of effect might have been attributed to an inappropriate injection timing since it has been reported that 2 or 4 daily $\mathrm{GH}$ injections $(22,24)$, or even continuous $\mathrm{GH}$ administration (25) are more effective than one single injection in stimulating bone growth. To evaluate this possibility a second experiment was designed in which different $\mathrm{GH}$ administration schedules were tested, while maintaining the same total dosage.

No effect on bone growth in peripubertal male rats could be observed with 3 daily injections, or one single injection at different hours of the day or a continuous GH s.c. infusion. The possibility that inadequate timing of $\mathrm{GH}$ administration was responsible for the lack of effect was thus discarded. However, the observed reduction in endogenous plasma rat growth hormone levels, in accordance with Maiter et al. (26) and Domené et al. (19) indicates a negative feedback of rhGH on endogenous rat $\mathrm{GH}$ secretion and, therefore, the effectiveness of rhGH exogenous administration.

Although GH administration to young normal male rats generally has no effect on body weight $(26,27)$, some authors have found a slight stimulatory effect on this parameter after 7 days of the injection of $0.084 \mathrm{mg} /$ rat/day rhGH (19) or IGF-I (28). Since GH was found to be more effective in promoting growth than IGF-I (8), we used GH at higher doses than those used by Domené et al. (19), and studied the animals for a considerably longer period of time, without observing any weight increment. Nevertheless, it must be taken into account that detecting weight gain does not necessarily mean growth, and vice versa; GH metabolic and growth promoting effects can follow different paths, since in obese $\mathrm{dw} / \mathrm{dw}$ rats $\mathrm{GH}$ infusions induced weight loss while GH injections caused weight gain, and both treatments stimulated skeletal growth (29).

It is very important to point out that in our study the same rhGH dose that proved ineffective in peripubertal males was, however, able to stimulate growth in peripubertal female rats. Similar $\mathrm{GH}$ doses have also been described to stimulate growth in females by other authors, although expressed in terms of accumulated tibial growth (9), differences in final length (10), or changes in weight or tail length (30) instead of daily tibial length evolution as we are herewith reporting.

Human recombinant $\mathrm{GH}$ is antigenic in the rat (30) and thus, during long-term treatments, a certain waning effect of the growth rate stimulation (31) could be expected due to the formation of rhGH antibodies. However, this phenomenon cannot be held responsible for the total lack of growth enhancement in peripubertal male rats, since the same absence of response should also have appeared in female rats. In addition, no GH toxic effects should be expected since the doses used in the present study were much lower than those associated with important side effects, as shown by Groesbeck et al. (30).

$\mathrm{GH}$ administration to peripubertal rats was not associated with an increase in plasma IGF-I levels, as has been reported previously $(20,23,32)$. GH can promote growth without inducing significant changes in plasma IGF-I levels as was the case in females (32). Local rather than circulating levels of IGF-I concentrations seem to be the crucial growth factor (33), and are probably regulated by IGF binding proteins (34).

We are proposing that normal male rats do in fact grow at maximum speed during the peripubertal period, and exogenous rhGH administration was not able to increase it. Female rats of the same age grow at a slower rate than males $(35,36)$, allowing their potentiation by exogenous rhGH treatment. Since rhGH treatment has been shown to promote growth in 3-month-old male 
rats (37) as measured by femur length or body weight (26), the possibility that this could be due to the slowing down of growth rate at this age needed to be tested. To prove this hypothesis, normal males of 96 days of age were submitted to the same GH dose and treatment schedule that proved unsuccessful in peripubertal males, finding this time an increase in their tibial length growth rate.

Other data from the literature show that rat growth rate can be accelerated with GH only when animals have finished the highly active growing pubertal period. Genetic large (LL) rats (38), or hGH transgenic rats (39, 40 ), or even rats implanted with a GH secreting tumor (26) showed higher body weight than controls only when animals were older than our peripubertally GHtreated males.

Catch-up growth following a period of growth arrest (as occurs during starvation) is another situation in which growth rate has been shown to be augmented. This process, however, has mostly been investigated by using changes in weight as an index for growth (see 42 for review).

We submitted normal peripubertal male rats to a period of food restriction, and observed a dramatic weight loss followed by a catch-up during refeeding. Although all groups tended to recover their normal weight, recovery was incomplete at the end of the experiment. It seems that reaching a complete recovery also depends on the time of onset of growth retardation (42) or on the necessity of additional time.

The picture was somewhat different for leg length growth, since no catch-up effect was observed. The different groups submitted to starvation showed the same growth pattern after refeeding as normally fed animals. However, the groups had lower leg lengths at the end of the study due to the growth arrest during the starvation period. None of the GH treatments was able to change the evolution of weight or tibial growth. As a result, the loss of tibial growth was not recovered and the final leg length was lower in starved animals. These results reinforce our hypothesis that normal peripubertal males show a maximal growth speed that apparently cannot be further improved. Phillips and Young (43) reported that starvation reduces the incorporation of $\mathrm{SO}_{4}$ to the growth plate. This effect was reversed by refeeding but incorporation of $\mathrm{SO}_{4}$ did not surpass the levels observed in well-fed one-month-old male rats, implying that no supraphysiological growth (catch-up) occurs.

Other studies by our group (2) have demonstrated that, when animals older than those used in these experiments were submitted to food restriction, they exhibited a mild leg length growth stimulation and a rapid and complete weight catch-up when refeeding.

Other authors (44) have pointed out the possibility that male rats grow at a maximal velocity during peripuberty but no conclusive data have so far been presented. Our results help support this hypothesis and show the necessity of a more careful specification when describing $\mathrm{GH}$ effect on normal rats. We also advise using long bone growth estimations instead of body weight when evaluating growth processes. Our data on catch up-growth and bibliographic references reinforce the existing differences between these parameters.

\section{Acknowledgements}

The authors thank the National Hormone Pituitary Program for the GH RIA reagents and IGF-I antibody, Lilly Company for the IGF-I standard and Serono for providing the rhGH. We want to give thanks to Lucila Kraus, Antonio Carmona and Blanca Martínez for their technical assistance. This work has been supported by FISS number 94/0389, Spain.

\section{References}

1 Hermanussen M, Rol de Lama MA, Burmeister J \& Tresguerres JAF. Mikro-knemometry: an accurate technique of growth measurements in rats. Physiology and Behaviour 199558 347352.

2 Hermanussen M, Rol de Lama MA, Pérez-Romero A, Ariznavarreta C, Burmeister J \& Tresguerres JAF. Differential catch-up in body weight and bone growth after short-term starvation in rats. Growth Regulation 19966 230-237.

3 Tresguerres JAF, Pérez-Romero A, Rol de Lama MA, Granados B, Hermanussen M \& Ariznavarreta C. Minigrowth spurts: influence of sexual hormones and GH. In Frontiers in Endocrinology, vol 10. Puberty: Basic and Clinical Aspects. Eds C Bergada \& JA Moguilevsky. Rome, Italy: Ares Sereno Symposia, 1995.

4 Rol de Lama MA, Pérez-Romero A, Hermanussen M, Ariznavarreta C \& Tresguerres JAF. Sexual dimorphism in growth as measured by microknemometry: different responses to GH deficiency and exogenous GH administration. Neuroendocrinology 199868 210-219.

5 Rol de Lama MA, Pérez-Romero A, Hermanussen M, Ariznavarreta C \& Tresguerres JAF. Periodic growth in rats. Annals of Human Biology $199825441-451$.

6 Cheek O \& Hill DE. Effect of growth hormone on cell and somatic growth. In Handbook of Physiology, vol 4, pp 159-185. Eds E Knobil \& E Sawter. Washington DC: American Physiological Society, 1974.

7 Martínez DA, Orth MW, Carr KE, Vanderby Jr R \& Vailas AC. Cortical bone growth and maturational changes in dwarf rats induced by recombinant human growth hormone. American Journal of Physiology 1996270 E51-E59.

8 Isgaard J, Nilsson A, Lindahl A, Jansson JO \& Isaksson OGP. Effects of local administration of GH and IGF-I on longitudinal bone growth in rats. American Journal of Physiology 1986250 E367E372.

9 Aspenberg P, Hansson LI \& Thorngren KG. Modification of bone formation rate by growth hormone, melanocyte-stimulating hormone, and cortisone in the normal rat. Acta Anatomica $198512184-88$.

10 Jørgensen PH, Bak B \& Andreassen TT. Mechanical properties and biochemical composition of rat cortical femur and tibia after longterm treatment with biosynthetic human growth hormone. Bone $199112353-359$.

11 Harel Z \& Tannenbaum GS. Long term alterations in growth hormone and insulin secretion after temporary dietary protein restriction in early life in the rat. Pediatric Research 199538 747753.

12 Lanz JK, Donahoe M, Rogers RM \& Ontell M. Effects of growth hormone on diaphragmatic recovery from malnutrition. Journal of Applied Physiology 199273 801-805. 
13 Mosier HD Jr, Dearden LC, Jansons RA \& Hill RR. Cartilage sulfacation during catch-up growth after fasting in rats. Endocrinology $1978102386-392$.

14 Lima L, Arce V, Tresguerres JAF \& Devesa J. Clonidine potentiates the $\mathrm{GH}$ response to GHRH in norepinephrine synthesis inhibited rats: evidence for an $\alpha 2$ adrenergic control of hypothalamic release of somatostatin. Neuroendocrinology 199357 1155-1166.

15 Ruiz A, Tébar M, Pérez-Romero A, Rol de Lama MA \& SánchezCriado JE. Serum levels of GH, IGF-I, LH and ovarian steroids in cyclic and RU486-treated rats. Journal of Endocrinological Investigation $199720611-615$.

16 Daughaday WH, Mariz IK \& Blethen SL. Inhibition of access of bound somatomedin to membrane receptor and immunobinding sites: a comparison of radioreceptor and radioimmunoassay of somatomedin in native and acid-ethanol extracted serum. Journal of Clinical Endocrinology and Metabolism 198051 781-788.

17 Daughaday WH, Parker KA, Borowsky S, Trivedi B \& Kapadia M. Measurement of somatomedin-related peptides in fetal, neonatal, and maternal rat serum by insulin-like growth factor (IGF)-I radioimmunoassay, IGF-II radioreceptor assay (RRA), and multiplication-stimulating activity RRA after acid-ethanol extraction. Endocrinology 1982110 575-581.

18 Bang P, Baxter RC, Blum WF, Breier BH, Clemmons DR, Hall K et al. Valid measurements of total IGF concentrations in biological fluids. Recommendations from the 3rd International Symposium on Insulin-like Growth Factors. Endocrinology 1995136816 817.

19 Domené H, Krishnamurthi K, Eshet R, Gilad I, Laron Z, Koch I et al. Growth hormone (GH) stimulates insulin-like growth factorI (IGF-I) and IGF-I-binding protein-3, but not GH receptor gene expression in livers of juvenile rats. Endocrinology 1993133 675682.

20 Byatt JC, Staten NR, Salsgiver WJ, Kostelc JG \& Collier RJ. Stimulation of food intake and weight gain in mature female rats by bovine prolactin and bovine growth hormone. American Journal of Physiology 19936 E986-E992.

21 Azain MJ, Roberts TJ, Martin RJ \& Kasser TR. Comparison of daily versus continuous administration of somatotropin on growth rate, feed intake, and body composition in intact female rats. Journal of Animal Science 199573 1019-1029.

22 Jansson JO, Alberstsson-Wikland K, Edén S, Thorngren KG \& Isaksson $\mathrm{O}$. Effect of frequency of growth hormone administration on longitudinal bone growth and body weight in hypophysectomized rats. Acta Physiologica Scandinavica 1982114 261-265.

23 Clark RG, Mortensen DL, Carlsson LMS, Spencer SA, McKay P, Mulkerrin $\mathrm{M}$ et al. Recombinant human growth hormone (GH)binding protein enhances the growth-promoting activity of human GH in the rat. Endocrinology $19961374308-4315$

24 Jansson JO, Albertsson-Wikland K, Edén S, Thorngren KG \& Isaksson OGP. Circumstantial evidence for a role of the secretory pattern of growth hormone in the control of body growth. Acta Endocrinologica 198299 24-30.

25 Cotes PM, Bartlett WA, Gaines Das RE, Flecknell P \& Termeer R. Dose regimens of human growth hormone: effects of continuous and of gelatin vehicle on growth in rats and rate of absorption in rabbits. Journal of Endocrinology 198087 303-312.

26 Maiter DM, Gabriel SM, Koening JI, Russel E \& Martin JB. Sexual differentiation of growth hormone feedback effects on hypothalamic growth hormone-releasing hormone and somatostatin. Neuroendocrinology 199051 174-180.

27 Ohashi S, Kaji H, Abe H \& Chihara K. Effect of fasting and growth hormone $(\mathrm{GH})$ administration on $\mathrm{GH}$ receptor (GHR) messenger ribonucleic acid (mRNA) and GH-binding protein (GHBP) mRNA levels in male rats. Life Science 199558 1655-1666.
28 Hizuka N, Takano K, Asakawa K, Sukegawa I, Horikawa R, Kikuchi $\mathrm{H}$ et al. Biological action of insulin-like growth factor-I in vivo. Basic and clinical aspects of growth hormone. Serono Symposia, pp 223-231. Ed BB Bercu. New York: Plenum Press, 1988.

29 Clark RG, Mortenssen DL, Carlsson LM, Carlsson B, Carmignac D \& Robinson ICAF. The obese growth hormone (GH)-deficient dwarf rat: body fat responses to patterned delivery of $\mathrm{GH}$ and insulin-like growth factor-I. Endocrinology 1996137 1904-1912.

30 Groesbeck MD, Parlow AF \& Daughaday WH. Stimulation of supranormal growth in prepubertal adult plateaued, and hypophysectomized female rats by large doses of rat growth hormone: physiological effects and adverse consequences. Endocrinology $19871201963-1975$.

31 Fielder PJ, Mortenssen DL, Mallet P, Carlsson B, Baxter RC \& Clark RG. Differential long-term effects of insulin-like growth factor-I (IGF-I), growth hormone (GH), and IGF-I plus GH on body growth and IGF binding proteins in hypophysectomized rats. Endocrinology 1996137 1913-1920.

32 Loveridge N, Farquharson C, Palmer R, Lobley GE \& Flint DJ. Growth hormone and longitudinal bone growth in vivo: shortterm effect of a growth hormone antiserum. Journal of Endocrinology 1995146 55-62.

33 Flyvbjerg A, Jørgenssen KD, Marshall SM \& Ørskov H. Inhibitory effect of octreotide on growth hormone-induced IGF-I generation and organ growth in hypophysectomized rats. American Journal of Physiology 1991260 E569-E576.

34 Steward CEH \& Rotwein P. Growth, differentiation, and survival: multiple physiological functions for insulin-like growth factors. Physiological Reviews 199676 1005-1026.

35 Jansson JO, Edén S \& Isaksson O. Sexual dimorphism in the control of growth secretion. Endocrine Reviews $19856128-150$.

36 Hughes PCR \& Tanner JM. A longitudinal study of the growth of the black-hooded rat: methods of measurement and rates of growth for skull, limbs, pelvis, nose-rump and tail lengths. Journal of Anatomy 1970106 349-370.

37 Ørtoft G, Oxlund H, Jørgenssen PH \& Andreassen TT. Glucocorticoid treatment and food deprivation counteract the stimulating effect of growth hormone on rat cortical bone strength. Acta Padiatrica $199281912-917$.

38 O'Sullivan D, Millard WJ, Badger TM, Martin JB \& Martin RJ. Growth hormone secretion in genetic large (LL) and small (SS) rats. Endocrinology $19861191948-1953$.

39 Ikeda A, Matsuyama S, Nishihara M, Tojo H \& Takahashi M. Changes in endogenous growth hormone secretion and onset of puberty in transgenic rats expressing human growth hormone gene. Endocrine Journal 199441 523-529.

40 Ikeda A, Chang KT, Matsumoto Y, Furuhata Y, Nishihara M, Sasaki F et al. Obesity and insulin resistance in human growth hormone transgenic rats. Endocrinology $19981393057-3063$.

41 Boersma B \& Wit JM. Catch-up growth. Endocrine Reviews 1997 18 646-661.

42 Mosier HD Jr. The control of catch-up growth. Acta Endocrinologica 1986279 (Suppl) 1-7.

43 Phillips LS \& Young H. Nutrition and somatomedin I. Effect of fasting and refeeding on serum somatomedin activity and cartilage growth activity in rats. Endocrinology $197699304-314$.

44 Froesch ER, Guler HP, Schmid C, Binz K \& Zapt J. Therapeutic potential of insulin like growth factor-I. Trends in Endocrinology and Metabolism $19901254-260$.

Received 21 July 1999

Accepted 22 December 1999 